\title{
In vitro evaluation of synergistic inhibitory effects of neuraminidase inhibitors and Methylglyoxal against Influenza virus infection
}

インフルエンザウィルス感染に対する Methylglyoxal と Neuraminidase 阻害薬の併用に よる相乗的阻害効果についての検討

長崎大学大学院医歯薬学総合研究科 新興感染症病態制御学系専攻 SIRIWAN CHARYASRIWONG（チャリャシリワンシリワン）

\section{【目的】}

インフルエンザウィルスは、インフルエンザ疾患を引き起こすオルソミクソウィルス 科に属するウイルスであり、毎年冬季に流行し多数の罹患者を出している。また近年で は、ヒトーヒト間で感染性を示す高病原性新型インフルエンザウイルスの出現と世界的 大流行 (パンデミック) の発生が懸念されており、有効な防疫策の構築が急務である。 インフルエンザウイルスに対する現行の防疫策としては、ワクチン接種による予防と抗 ウイルス薬による治療に大別される。しかしながら、インフルエンザウイルスでは変異 株が高頻度で出現するため、ワクチンの効果も限定的であり、有効な治療薬であっても 而性株出現の問題が看過できない。治療薬は、タミフル、リレンザ、イナビル、ラピア クタといった neuraminidase 阻害薬が開発され使用されているが、最も多用されている タミフルに関しては既に薬剤而性株の出現が確認されており、新規抗インフルエンザウ イルス剤の開発が常に求められている。

蜂蜜は食品としてだけでなく民間療法に用いられてきた歴史がある。これまでの検討 から我々は蜂蜜の成分である MGO に抗インフルエンザウイルス活性を見出してきた。 MGO の示す抗インフルエンザウィルス活性の作用機序としては、ウィルス粒子に直接的 に作用していることが示唆されている。一方、既存薬である各種 NA 阻害剤は感染細胞 からの新生ウィルス粒子の放出過程を阻害することが知られている。本研究では作用機 序の異なる MGO と NA 阻害剤の併用効果について検討することを目的とした。

\section{【方法】}

（1)活性確認試験：96 ウェルプレートに $\mathrm{MDCK}$ 細胞を播種し、 $37^{\circ} \mathrm{C} \quad 5 \% \mathrm{CO}_{2}$ 下で一晚 培養した。細胞を無血清培地で一度洗浄した後、計 4 種の抗インフルエンザウイルス薬 と MGO について抗ウイルス活性を確認するため、計 5 株の A 型インフルエンザウイル スと 6 株の B 型インフルエンザウィルスを各薬剤の段階希釈系列存在下に細胞に感染さ せた。ウィルスは $100 \mathrm{TCID}_{50} /$ well $(\mathrm{MOI} \fallingdotseq 0.002$ に相当)の感染力価で添加した。また、 各薬剂の細胞毒性評価のため、段階希釈した薬剤のみを細胞に添加した。ウイルス及び 薬剂添加後、 $37^{\circ} \mathrm{C} \quad 5 \% \mathrm{CO}_{2}$ 下で 3 日間培養した後、細胞を $70 \%$ エタノールで固定し、 クリスタルバイオレットでウイルス感染に伴う CPE(cytopathogenic effect：細胞変性効 果)を免れた残存細胞を染色した。染色液を除去し、水で軽くリンスした後風乾させた。 風乾後のプレートについてプレートリーダーで $560 \mathrm{~nm}$ における吸光度を測定し定量し た。各薬剤については、50\%感染阻害濃度（ $\mathrm{IC}_{50} ； 50 \%$ inhibitory concentration）及び 50\%細胞毒性濃度（ $\mathrm{CC}_{50} ; 50 \%$ cytotoxic concentration）を算定し、さらに薬剤の有効性 の指標とされる SI（selectivity index）を算出した。

(2)既存の抗ウィルス薬と MGOの併用効果の検討:MDCK細胞に段階希釈したタミフル、 リレンザ、イナビルまたはラピアクタと、段階希釈した MGO を同時に添加し、A/WSN/33 とタミフル耐性株である A/Nagasaki/HA-58（A/HA-58)を感染させた。（1）と同様にし て感染 3 日後細胞を染色し定量・解析した。 


\section{【結果】}

(1) $\mathrm{MGO}$ の A/WSN/33 株に対する $\mathrm{IC}_{50}$ 值は $0.24 \mathrm{mM}, \mathrm{CC}_{50}$ 值は $1.4 \mathrm{mM}$ と算定された。 $\mathrm{SI}\left(=\mathrm{CC}_{50} / \mathrm{IC}_{50}\right)$ は約 5.8 であった。 MGO はタミフル耐性株である A HA-58 株に対しても 抗ウイルス活性を示した。 $\mathrm{MGO}$ の $\mathrm{A} / \mathrm{HA}-58$ 株に対する $\mathrm{IC}_{50}$ 值は $0.25 \mathrm{mM}$ と算定され た。A/WSN/33 株と比較し、ほぼ同等であると考えられる。

(2) B 型インフルエンザウイルスに対する NA 阻害剂の効果はA型に対して同等か低い傾 向にあった。一方、 $\mathrm{B}$ 型インフルエンザウイルスに対する $\mathrm{MGO}$ の $\mathrm{IC}_{50}$ 值は $\mathrm{A}$ 型と比較 し顕著に低值を示し、B型株への有効性が確認された。さらに、MGO は NA 阻害剂に対 する感受性の有無によらず、いずれの株に対しても抗ウイルス活性を示すことが示唆さ れた。(Table 1.)。

Table1. 各 NA 阻害剂と MGO の異なるインフルエンザに対する $\mathrm{IC}_{50}$ 值一覧

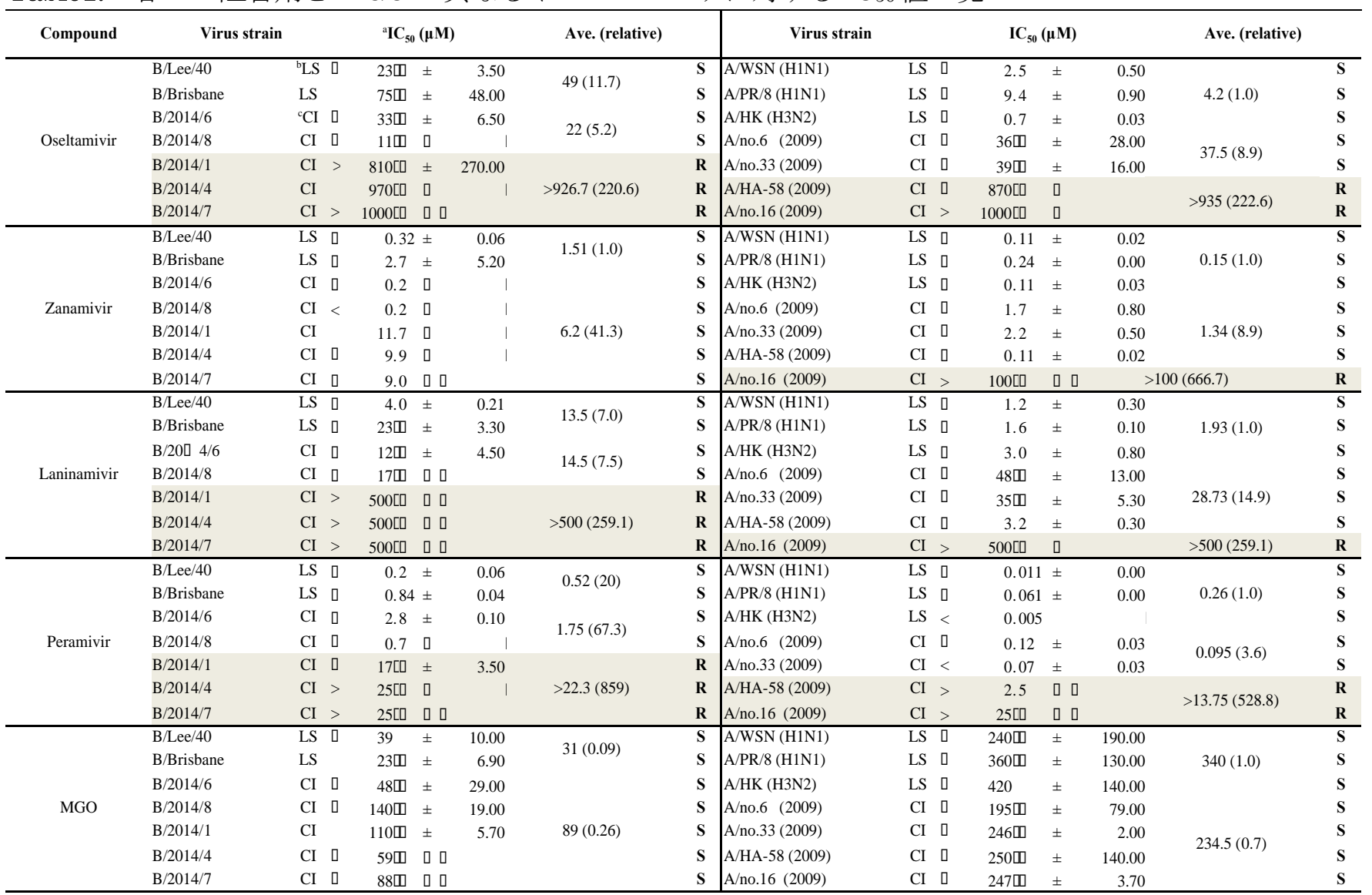

（3）各 NA 阻害剂を単独で作用させた際の $\mathrm{IC}_{50}$ 值と、 $\mathrm{MGO}$ を NA 阻害剂と同時に作用 させた際の $\mathrm{IC}_{50}$ 值を比較したところ、いずれの $\mathrm{NA}$ 阻害剤についても $\mathrm{IC}_{50}$ 值が $\mathrm{MGO}$ の 併用により顕著に減少することが示唆された。(Table 2.)。タミフル、リレンザ、イナビ ル、ラピアクタの $\mathrm{IC}_{50}$ 值は $174 \mu \mathrm{M}$ の $\mathrm{MGO}$ の併用により、それぞれほぼ 100 分の 1 、 300 分の $1 、 30$ 分の $1 、 200$ 分の 1 に減少した。

Table2. MGO 共添加時における各 NA 阻害剤の $\mathrm{IC}_{50}$ 值一覧

\begin{tabular}{cccccccccc} 
Conc, of & \multicolumn{2}{c}{ oseltamivir } & \multicolumn{2}{c}{ zanamivir } & \multicolumn{2}{c}{ laninamivir } & \multicolumn{2}{c}{ peramivir } \\
\cline { 2 - 9 } $\mathrm{MGO}(\mu \mathrm{M})$ & $\mathrm{IC}_{50}(\mu \mathrm{M})$ & Relative ratio & $\mathrm{IC}_{50}(\mu \mathrm{M})$ & Relative ratio & $\mathrm{IC}_{50}(\mu \mathrm{M})$ & Relative ratio & $\mathrm{IC}_{50}(\mu \mathrm{M})$ & Relative ratio \\
\hline 0 & $1.8 \pm 0.08$ & 1.0 & $0.30 \pm 0.19$ & 1.0 & $0.25 \pm 0.01$ & 1.0 & $0.028 \pm 0.015$ & 1.0 \\
5.4 & $2.0 \pm 0.31$ & 1.1 & $0.37 \pm 0.25$ & 1.2 & $0.22 \pm 0.03$ & 0.86 & $0.0055 \pm 0.001$ & 0.20 \\
22 & $0.58 \pm 0.22$ & 0.32 & $0.046 \pm 0.02$ & 0.15 & $0.14 \pm 0.07$ & 0.53 & $0.0033 \pm 0.0020$ & 0.12 \\
170 & $<0.020$ & $<0.011$ & $<0.0010$ & $<0.0033$ & $<0.010$ & $<0.04$ & $0.0033 \pm 0.0020$ & $<0.0054$ \\
\hline
\end{tabular}


（4）タミフル耐性株に対する MGO と NA 阻害剤の併用効果について検討した結果、タ ミフル耐性株に対しても、MGO と NA 阻害剂の併用により、相乗効果がみとめられた。 さらに、相乗効果は MGO の濃度依存的に増強することが確認された(Table 3)。

Table 3. タミフル而性株に対する MGO とタミフルの併用効果

\begin{tabular}{ccccc}
\hline $\begin{array}{c}\text { Concentration of } \\
\text { MGO } \\
(\mu \mathrm{M})\end{array}$ & \multicolumn{2}{c}{$6.25 \mathrm{TCID}_{50}$} & \multicolumn{2}{c}{$100 \mathrm{TCID}_{50}$} \\
\cline { 2 - 5 } & $\begin{array}{c}\mathrm{IC}_{50} \text { of } \\
\text { oseltamivir }(\mu \mathrm{M})\end{array}$ & $\begin{array}{c}\text { Relative } \\
\text { ratio }\end{array}$ & $\begin{array}{c}\mathrm{IC}_{50} \text { of } \\
\text { oseltamivir }(\mu \mathrm{M})\end{array}$ & $\begin{array}{c}\text { Relative } \\
\text { ratio }\end{array}$ \\
\hline 200 & 110 & 1 & $>1000$ & 1 \\
25 & 7.7 & 0.55 & $\mathrm{ND}$ & $\mathrm{N} / \mathrm{A}$ \\
100 & $<3.9$ & 0.038 & $\mathrm{ND}$ & $\mathrm{N} / \mathrm{A}$ \\
125 & $<3.9$ & $<0.019$ & 448 & $<0.45$ \\
250 & & $<0.019$ & 46 & $<0.046$ \\
\hline
\end{tabular}

\section{【考察】}

本研究より、MGO はインフルエンザウイルスに対して、血清型や薬剤感受性によらず、 いずれの株に対しても抗ウイルス活性を示すことが示唆された。

$\mathrm{B}$ 型インフルエンザウイルスは A 型と同様オルソミクソウィルス科に属する同属のウ イルスであるが、既存の NA 阻害剂に対する効果に差異が確認された。NA 阻害剂は A 型株に対する抑制効果が B 型株よりも高い可能性が示唆された。一方、MGO は B 型株 に対してより低值の $\mathrm{IC}_{50}$ 值を示し、A 型株よりも有效性が高いことが確認された。

本研究より、MGO は既存の NA 阻害薬と併用することでインフルエンザウイルスに対 する感染抑制効果を顕著に増強することが明らかとなった。計 4 種の NA 阻害剂

(Oseltamivir, Zanamivir, Laninavir, Peramivir) の単独添加時における $\mathrm{IC}_{50}$ 值が、 MGO の濃度依存的に、各々最大で約 100 分の 1 、300 分の 1 、30 分の $1 、 200$ 分の 1 に減少し、抑制効果の増強が確認された。

インフルエンザウイルスにおける抗ウイルス剤の相乗効果の作用メカニズムについて はさらに検討する必要があるが、異なる作用機構の抗ウイルス剂の併用は AIDS におい て HAART 療法としてその有用性が確立しており、インフルエンザウイルス治療におい ても使用薬剤量の低減、薬剤耐性ウイルスの出現の低減という観点からも検討すべき課 題であると考えられる。

\section{【基礎となった学術論文】}

1. Charyasriwong S., Watanabe K., Rahmasari R., Matsunaga A., Haruyama T., Kobayashi N. In Vitro Evaluation of Synergistic Inhibitory Effects of Neuraminidase Inhibitors and Methylglyoxal Against Influenza Virus Infection Archives of Medical research, 46, 8-16 (2015)

2. Charyasriwong S., Haruyama T., Kobayashi N. In vitro evaluation of the antiviral activity of methylglyoxal against influenza $B$ virus infection Drug Discoveries \& Therapeutics. 10(4) 201-210 (2016). 